\title{
DUKUNGAN BADAN PEMERIKSA KEUANGAN REPUBLIK INDONESIA DALAM PENYELESAIAN SENGKETA KONSTRUKSI (MERUJUK UU NO.2/2017 PSL 88)
}

\author{
Mega Maharani Hutahaean ${ }^{1}$ dan Sarwono Hardjomuljadi²
}

\author{
${ }^{1}$ Prodi Magister Teknik Sipil, Universitas Tarumanagara, Jl. Letjen S. Parman No. 1 Jakrata Barat, 11440 \\ Email korespondensi: megahutahaean@yahoo.com \\ ${ }^{2}$ Prodi Magister Teknik Sipil, Universitas Tarumanagara, Jl. Letjen S. Parman No. 1 Jakrata Barat, 11440 \\ Email: sarwonohm2@gmail.com
}

\begin{abstract}
ABSTRAK
Latar belakang yang mendasari penelitian ini adalah permasalahan-permasalahan sekitar pelaksanaan konstruksi yang berhubungan dengan faktor biaya, mutu, dan waktu. Hal ini terjadi karena pelaku dalam industri konstruksi tidak mentaati apa yang sudah tertulis dan disepakati bersama dalam suatu kontrak konstruksi. Topik ini menjadi menarik ketika banyak sekali persoalan menyangkut kegiatan konstruksi yang berlaku di Indonesia tetapi penyelesaiannya merugikan salah satu pihak yang merasa sudah menjalankan tugas dan kewajibannya tanpa ada telaahan atau kajian terhadap permasalahan serupa yang bisa dijadikan acuan alternatif penyelesaian sengketa. Penelitian ini bertujuan untuk mendapatkan pemahaman bahwa Badan Pemeriksa Keuangan Republik Indonesia (BPK RI) melalui hasil pemeriksaannya dapat mendukung penyelesaian sengketa yang sering terjadi di industri konstruksi. Dengan menggunakan metode penelitian deskriptif yaitu dengan melakukan pengumpulan data primer melalui permintaan data langsung ke satuan kerja PPID BPK RI berupa data pengaduan yang berasal dari eksternal BPK RI baik masyarakat, lembaga sosial masyarakat, rekanan swasta, BUMN/D, Pemerintah Pusat/Daerah, DPR/DPD/DPRD, Laporan Hasil Pemeriksaan BPK RI yang sudah terbit dari portal BPK RI https://portal.bpk.go.id/. Data yang didapatkan diolah dengan membuat matriks pengelompokkan atas permasalahan yang sering terjadi di industri konstruksi. Pengolahan data dilakukan dengan tujuan mencari dan menguraikan keterkaitan output sekecil apapun dari BPK RI yang berhubungan dengan dunia konstruksi sebagai alternatif penyelesaian masalah yang dihadapi pihak-pihak yang bersengketa.
\end{abstract}

Kata kunci: sengketa konstruksi, Pemeriksaan BPK RI

\begin{abstract}
The background that underlies this research report is the problems surrounding the implementation of construction related to the factors of cost, quality, time. This happens because actors in the construction industry do not obey what has been written and agreed in the construction contract. This topic becomes interesting when there are many risk construction problems in Indonesia, but the resolution is disadvantage to one of the parties who have carried out their duties and obligations without any analysis or study of the problems that can be used as an alternative reference for dispute resolution. This study aims to gain an understanding that the Supreme Audit Agency of Republic of Indonesia (BPK RI) through its investigation results can support dispute resolution that often occurs in the construction world (industry). By using the descriptive research method, namely by collecting primary data through direct data requests to the PPID BPK RI work unit in the form of complaint data originating from external BPK RI, both from the community, community social institutions, private partners, $B U M N$ / D, Central / Regional Government, DPR / DPD / DPRD, BPK RI Audit Results Report that has been published from the BPK RI portal https://portal.bpk.go.id/. The data obtained is processed by creating a grouping matrix for problems that often occur in the construction world (industry). Data processing is carried out with the aim of finding and describing the slightest output linkages from BPK RI which are related to the world of construction as an alternative to solving problems faced by the disputing parties.
\end{abstract}

Keywords: construction dispute, Audit of BPK RI 


\section{PENDAHULUAN}

Kegiatan konstruksi di Indonesia yang terus berkembang secara nyata memperlihatkan bahwa pihak-pihak yang terlibat didalamnya tetap berusaha agar hubungan ini tetap berkelanjutan. Para pihak yang dimaksud dalam pengikatan jasa konstruksi adalah pengguna jasa dan penyedia jasa baik perseorangan atau badan. Pengikatan hubungan kerja Jasa Konstruksi dilakukan berdasarkan prinsip persaingan yang sehat dan dapat dipertanggungjawabkan secara keilmuan. Hubungan pengikatan jasa konstruksi ini didasari oleh itikad baik masing-masing pihak. Akan tetapi walaupun sudah berdasarkan itikad baik tetap saja akan selalu timbul permasalahanpermasalahan ataupun perbedaan paham, pertentangan mulai dari yang sederhana sampai yang rumit, sehingga berpotensi menjadi sengketa hukum (law disputes). Untuk menyelesaikan permasalahan sengketa konstruksi, para pihak yang bersengketa menempuh penyelesaian sesuai Undang-Undang Jasa Kostruksi No 2 Tahun 2012. Dalam pasal 88, disebutkan penyelesaian sengketa konstruksi melalui Mediasi dan Konsiliasi atau dapat juga digantikan dengan Dewan Sengketa, dan melalui arbitrase.

\section{LATAR BELAKANG}

Pada umumnya bila sudah terjadi sengketa konstruksi, pihak-pihak yang bersengketa membutuhkan pihak netral untuk menyelesaikan atau menjadi acuan dalam penyelesaian sengketa, karena pihak netral diharapkan tidak berat kepada satu pihak saja.

Lazimnya proyek konstruksi di Indonesia untuk tujuan pembangunan negara dan atau daerah menggunakan Anggaran Pendapatan dan Belanja Negara/Daerah (APBN/D). Hal ini menjadi suatu keharusan bagi Pemerintah untuk melakukan memeriksa dan memberikan pendapat terhadap pelaksanaan proyek konstruksi yang sudah dilakukan. Hal ini menjadi tugas Badan Pemeriksa Keuangan (BPK) dalam menjalankan tugas dan wewenangnya melakukan pemeriksaan terhadap kepatuhan perundang-undangan atas penggunaan anggaran negara/daerah untuk proyek konstruksi.

BPK RI berdasarkan pada nilai-nilai Independensi, Integritas dan Profesionalisme menjalankan pemeriksaan dan menerbitkan pendapat terhadap hasil pemeriksaan yang telah dilakukan. Hasil pemeriksaan yang dilakukan BPK RI bersifat final dan mengikat. Oleh karena itu pemeriksaan BPK RI dijadikan sebagai gambaran terhadap tata kelola keuangan negara yang bersih dan tertib.

Banyaknya sengketa dalam pelaksanaan konstruksi di Indonesia terutama yang menggunakan anggaran negara atau daerah dimanfaatkan sebaiknya oleh pihak yang bersengketa untuk melakukan pengaduan kepada lembaga audit pemerintah dalam hal ini BPK RI yang melibatkan masyarakat, lembaga sosial masyarakat, rekanan swasta, BUMN/D, Pemerintah Pusat/Daerah, ataupun DPR/DPD/DPRD, dengan tujuan agar BPK RI melakukan pemeriksaan terhadap proyek yang sedang berlangsung sehingga didapatkan hasil pemeriksaan yang dapat dijadikan gambaran bagi pihak yang bersengketa untuk menyelesaikan sengketa.

\section{METODE PENELITIAN}

Metode pengumpulan data menggunakan metode deskriptif, yaitu metode yang menggambarkan fenomena yang didasarkan pada pengalaman dan hasil pengamatan. Metode deskriptif dapat juga diartikan sebagai prosedur pemecahan masalah yang diselidiki dengan menggambarkan keadaan subyek atau obyek dalam penelitian dapat berupa orang, lembaga, masyarakat dan yang lainnya yang pada saat sekarang berdasarkan fakta-fakta yang tampak atau apa adanya. Sedangkan teknik pengumpulan data yang digunakan adalah dengan mengambil data pengaduan eksternal yang masuk ke BPK RI diambil dari Laporan Tahunan Pelayanan Informasi Publik BPK 
pada website https://e-ppid.bpk.go.id/, Laporan Hasil Pemeriksaan BPK RI yang sudah terbit dari portal BPK RI https://portal.bpk.go.id/, dan meminta langsung data pengaduan yang masuk ke BPK RI dari satuan kerja PPID BPK RI terkait kegiatan konstruksi di Indonesia. Permintaan data ke PPID BPK RI langsung dilakukan dengan mendatangi Biro Humas BPK RI dikarenakan data yang dibutuhkan merupakan salah satu informasi yang dikategorikan sebagai informasi yang dikecualikan yaitu informasi yang tidak dapat diakses oleh pemohon informasi publik sebagaimana dimaksud dalam Undang-Undang tentang Keterbukaan Informasi Publik.

Data permasalahan yang ada dalam LHP kemudian diolah dengan membuat matriks pengelompokkan atas permasalahan yang sering terjadi di industri konstruksi.

\section{ANALISA DAN PEMBAHASAN}

Berdasarkan Laporan Hasil Pemeriksaan (LHP) tahun 2019 atas Kementerian Perhubungan Republik Indonesia nomor 29b,c/HP/XIV/05/2019 tanggal 17 Mei 2019, Badan Pusat Statistik nomor 62b,c/LHP/XV/04/2019 tanggal 26 April 2019, Kementerian Pendidikan dan Kebudayaan Republik Indonesia nomor 1.b,c/HP/XIX/05/2019 tanggal 10 Mei 2019, Kementerian Pekerjaan Umum dan Perumahan Rakyat Republik Indonesia nomor 12.B,C/LHP/XVII/ 05/2019 tanggal 17 Mei 2019, Kementerian Agama Republik Indonesia nomor 27.B,C/LHP/XVIII/05/2019 tanggal 3 Mei 2019, Kementerian Kesehatan Republik Indonesia nomor 2b,c/HP/XIX/05/2019 tanggal 20 Mei 2019, dilakukan penelahaan hasil laporan dan diperoleh pemahaman bahwa hasil pemeriksaan BPK RI atas pekerjaan yang berhubungan dengan kegiatan konstruksi seringkali ditemukan permasalahan-permasalahan dan atas permasalahan tersebut dituangkan dalam temuan pemeriksaan beserta rekomendasi yang harus dilakukan sebagai perbaikan oleh entitas.
Setelah menelaah Laporan Hasil Pemeriksaan terdapat 25 jenis temuan yang sering muncul oleh Auditorat Keuangan Negara I - VII. Jenis temuan tersebut antara lain adalah:

1. Keterlambatan pekerjaan;

2. Keterlambatan pembayaran oleh owner;

3. Kelemahan administrasi/tidak tertib, tidak lengkap, hilang, dan lain-lain;

4. Syarat-syarat khusus kontrak dan Syarat-syarat umum kontrak yang tidak lengkap;

5. Tidak ada As Built Drawing (ABD) dan dokumentasi proyek;

6. Kualitas/mutu pekerjaan/cacat pekerjaan;

7. Kelebihan pembayaran akibat:

a. Kurang volume;

b. Pembayaran konsultan yang tidak melaksanakan pekerjaan;

c. Ketidaksesuaian spesifikasi pekerjaan dengan kontrak;

d. Pekerjaan belum selesai dikerjakan;

e. Kelebihan pembayaran $\mathrm{PPh}$;

8. Penyalahgunaan dana;

9. Pekerjaan konstruksi secara teknis belum dapat dipertanggungjawabkan;

10. Tenaga teknis tidak memiliki sertifikasi kecakapan dan sejenisnya;

11. Penunjukan konsultan tidak melalui penilaian memadai;

12. Tidak terdapat penilaian kinerja;

13. Belanja barang/jasa tidak sesuai ketentuan:

a. Pembayaran tidak dapat diyakini kewajarannya karena tidak diverifikasi

b. Tidak terdapat penyusunan dan penetapan HPS oleh PPK;

14. Pemecahan paket pekerjaan untuk menghindari seleksi;

15. Harga timpang lebih besar dari HPS (> $110 \%)$; 
16. Harga kontrak melebihi HPS;

17. Pemahalan pada harga atau pada koefisien pekerjaan;

18. Kemahalan pekerjaan;

19. Hasil pekerjaan tidak dapat berfungsi dengan optimal;

20. Pemutusan kontrak, pekerjaan belum $100 \%$ di akhir masa kontrak yang berakibat penerimaan negara dari pencairan Jaminan Pelaksanaan;

21. Bangunan tidak dapat dimanfaatkan dan berpotensi mangkrak;

22. Tidak ada justifikasi teknis untuk perubahan pekerjaan yang ada dalam konrak;

23. Pekerjaan tidak sesuai kontrak dalam kontrak lumpsum;

24. Indikasi persaingan tidak sehat sehingga berakibat pemborosan;

25. Realisasi keuangan tidak sesuai kemajuan fisik riil lapangan.

Adapun rekomendasi BPK untuk jenis-jenis temuan tersebut sangatlah beragam tergantung dari kontrak dan kompleksitas pekerjaan riil di lapangan. Berdasarkan pengelompokan yang sudah dilakukan dapat diketahui bahwa terdapat sembilan jenis temuan yang paling sering muncul dan diberikan rekomendasi oleh Auditorat Keuangan Negara I - VII. 9 jenis temuan tersebut diantaranya adalah:

1. Keterlambatan pekerjaan;

2. Kelemahan administrasi/tidak tertib, tidak lengkap, hilang, dll;

3. Kelebihan pembayaran akibat kurang volume, pembayaran konsultan, ketidaksesuaian spesifikasi pekerjaan , pekerjaan belum selesai dikerjakan, kelebihan pembayaran Pajak Penghasilan (PPh);

4. Penunjukan konsultan tidak melalui penilaian yang memadai;

5. Tidak terdapat penilaian kinerja;

6. Harga timpang $>110 \%$ (HPS);

7. Hasil pekerjaan tidak dapat berfungsi dengan optimal;
8. Pemutusan kontrak, pekerjaan belum $100 \%$ di akhir masa kontrak, yang berakibat penerimaan negara dari pencairan Jaminan Pelaksanaan;

9. Realisasi Keuangan tidak sesuai kemajuan fisik riil lapangan.

Berdasarkan Laporan Tahunan Pelayanan Informasi Publik PPID BPK RI didapatkan pengaduan dari pihak eksternal BPK. Pengaduan yang masuk melalui berbagai media yaitu melalui surat tertulis yang dikirim melalui pos, email ke biro humas humas@bpk.go.id, diantar langsung ke Pusat Informasi dan Komunikasi BPK, melalui kolom pengaduan di website E-PPID BPK. Semua pengaduan yang masuk di register, kemudian akan diperiksa kelengkapan pengaduan mulai dari identitas pengirim (nama dan alamat) dan dokumen pendukung pengaduannya.

Masyarakat saat ini bisa melakukan pengaduan ke BPK melalui berbagai media, dari hasil rekap pengaduan yang masuk dalam Laporan Tahunan Pelayanan Informasi Publik tiga tahun sejak 2017 2019 yang masuk ke BPK RI melalui PPID, akan dipilah dan diperiksa kelengkapannya oleh petugas PPID. Petugas PPID akan menginventarisir dan memilah pengaduan yang masuk dan menjadikannya ke dalam beberapa saringan yaitu: tahun pengaduan, tanggal pengaduan, nota dinas penyampaian pengaduan, status pengaduan yang dibagi menjadi status proses dan status selesai, satuan kerja terkait, posisi terakhir di satuan kerja terkait, tindak lanjut oleh satuan kerja, tindak lanjut oleh unit kerja Humas BPK RI, serta status penanganan oleh unit kerja Humas BPK RI yang dibagi menjadi tiga (3) status yaitu tidak dapat ditindaklanjuti, ditindaklanjuti, dan sebagai informasi.

Hasil inventarisir dari petugas PPID akan menghasilkan beberapa tindakan yang dilakukan oleh petugas PPID BPK RI, yaitu BPK RI hanya sebagai tembusan dan pengaduan akan di file, pengaduan akan diteruskan ke AKN terkait yang mengampu entitas yang di sebutkan dalam pengaduan, dikembalikan ke pengadu bila identitas dan 
dokumen pendukung tidak jelas, dan diberikan penjelasan langsung kepada pengadu bilamana pengadu langsung datang ke PPID BPK RI.

Pengaduan akan diteruskan ke AKN pengampu yang diadukan. Dalam hal pengaduan yang masuk diteruskan ke AKN terkait, tugas PPID beralih ke AKN tersebut. Dari hasil tindak lanjut status dan konfirmasi kepada petugas PPID, pengaduan yang diteruskan ke AKN akan di follow up perkembangan pengaduan tersebut dan dimintakan hasil atau proses yang sudah dilakukan oleh AKN. Pengaduan yang diterima dan sudah dilakukan telaah oleh AKN, akan menjadi jawaban yang digunakan PPID untuk memberikan surat jawaban kepada pengadu.

\section{Kasus pengaduan 1}

Surat pengaduan tanggal 16 Oktober 2018 yang mengadukan dugaan penyimpangan dalam pekerjaan pembangunan jaringan utama irigasi di Kabupaten OKU Timur Sumatera Selatan, terkait adanya potensi kerugian negara sebesar Rp17.000.000.000,00 dan adanya faktor kelemahan pemerintah. Setelah dilakukan penelaahan secara desk audit, diketahui bahwa identitas pelapor tidak didukung dokumen identitas lengkap dan dokumen penyedia jasa tidak tersedia seperti data ukur yang disajikan tidak ditandatangani oleh Konsultan selaku pemeriksa dan Pengawas Lapangan untuk mendapatkan persetujuan, sehingga dokumen yang disajikan belum memadai untuk dijadikan dasar penarikan kesimpulan yang komprehensif. Dimungkinkan bila diperlukan untuk pendalaman pemeriksaan atas paket tersebut akan dilaksanakan pada saat pemeriksaan atas Laporan Keuangan Kementerian Pekerjaan Umum dan Perumahan Rakyat Tahun Anggaran 2018.
Tabel 1. Ringkasan Kasus Pengaduan 1

\begin{tabular}{|l|l|}
\hline Judul & $\begin{array}{l}\text { Pengaduan atas dugaan } \\
\text { penyimpangan dalam } \\
\text { pekerjaan Pembangunan } \\
\text { Jaringan Utama Irigasi } \\
\text { Bahuga D.I. Komering Paket } \\
\text { II }\end{array}$ \\
\hline Vabupaten OKU Timur
\end{tabular}




\begin{tabular}{|c|c|}
\hline $\begin{array}{c}\text { c. Permas } \\
\text { alahan }\end{array}$ & $\begin{array}{l}\text { - Apakah benar telah terjadi } \\
\text { mark up volume timbunan } \\
\text { tanah seperti yang diduga } \\
\text { pelapor? } \\
\text { - Apakah telah terjadi } \\
\text { kerugian negara sebagai } \\
\text { akibat dari rekayasa } \\
\text { elevasi tanah asli dan mark } \\
\text { up volume timbunan } \\
\text { tanah? }\end{array}$ \\
\hline $\begin{array}{l}\text { d. Telaaha } \\
n\end{array}$ & 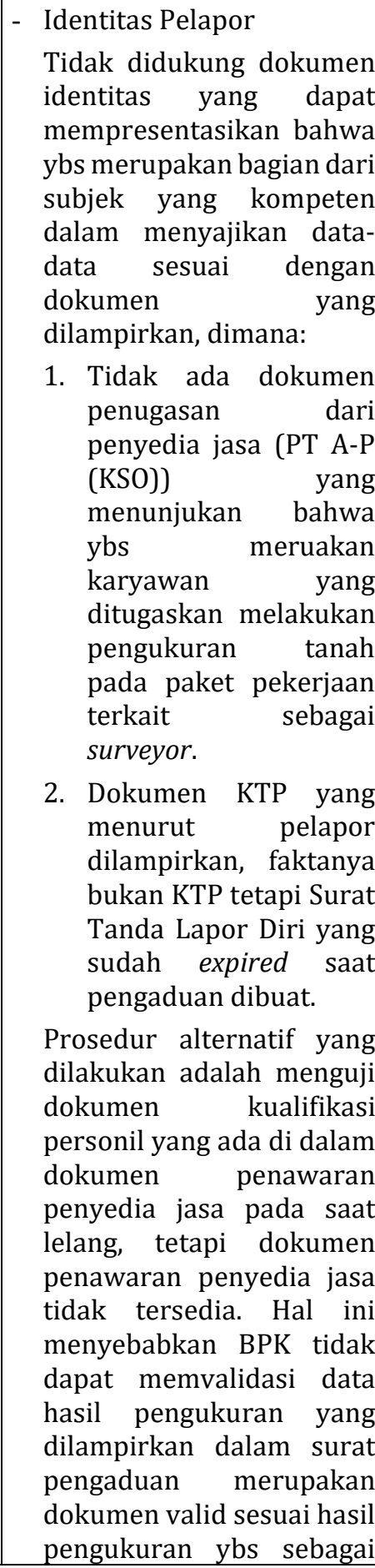 \\
\hline
\end{tabular}

\begin{tabular}{|c|c|}
\hline & $\begin{array}{l}\text { surveyor pada } \\
\text { pekerjaan terkait. }\end{array}$ \\
\hline e. Simpula & $\begin{array}{l}\text { - Identitas pengadu tidak } \\
\text { mempresentasikan bahwa } \\
\text { pelapor merupakan bagian } \\
\text { dari subjek yang kompeten } \\
\text { untuk menyajikan data } \\
\text { sesuai dengan dokumen } \\
\text { yang dilampirkan dalam } \\
\text { surat pengaduan; } \\
\text { - Dokumen } \\
\text { dilampirkan belum cukup } \\
\text { lengkap dan keabsahan } \\
\text { serta validitasnya masih } \\
\text { belum memadai sehingga } \\
\text { belum dapat dijadikan } \\
\text { sebagai dasar untuk } \\
\text { menarik kesimpulan yang } \\
\text { komprehensif. }\end{array}$ \\
\hline \multicolumn{2}{|c|}{ Surat Tanggapan BPK: } \\
\hline $\begin{array}{l}\text { a. } \begin{array}{l}\text { Nomor } \\
\text { surat }\end{array}\end{array}$ & $\begin{array}{l}\text { 558/S/X.2/11/2018, tanggal } \\
9 \text { November } 2018\end{array}$ \\
\hline $\begin{array}{l}\text { b. Asal } \\
\text { surat }\end{array}$ & $\begin{array}{l}\text { Biro Humas dan Kerja Sama } \\
\text { Internasional-BPK RI }\end{array}$ \\
\hline $\begin{array}{l}\text { c. Tujuan } \\
\text { surat }\end{array}$ & Si pengadu (Sdr. K) \\
\hline d. Perihal & $\begin{array}{l}\text { Tanggapan BPK atas } \\
\text { pengaduan masyarakat } \\
\text { terkait } \\
\text { penyimpangan } \\
\text { pekerjaan pembangunan } \\
\text { Jaringan Utama Irigasi } \\
\text { Bahuga D.I. Komering Paket } \\
\text { II Kabupaten OKU Timur, } \\
\text { Sumatera Selatan. }\end{array}$ \\
\hline e. Isi & $\begin{array}{l}\text { Berdasarkan hasil telaah, } \\
\text { BPK menyampaikan bahwa } \\
\text { dokumen yang diberikan si } \\
\text { pengadu belum cukup } \\
\text { lengkap dan keabsahan serta } \\
\text { validitasnya belum memadai } \\
\text { sehingga belum dapat } \\
\text { dijadikan sebagai dasar } \\
\text { untuk menarik kesimpulan } \\
\text { yang komprehensif, sebagai } \\
\text { berikut: } \\
\text { 1. Tidak terdapat dokumen } \\
\text { pendukung yang } \\
\text { meliputi back up quantity } \\
\text { dan monthly certificate, } \\
\text { dokumen pembayaran, } \\
\text { addendum kontrak dan } \\
\text { dokumen-dokumen foto }\end{array}$ \\
\hline
\end{tabular}




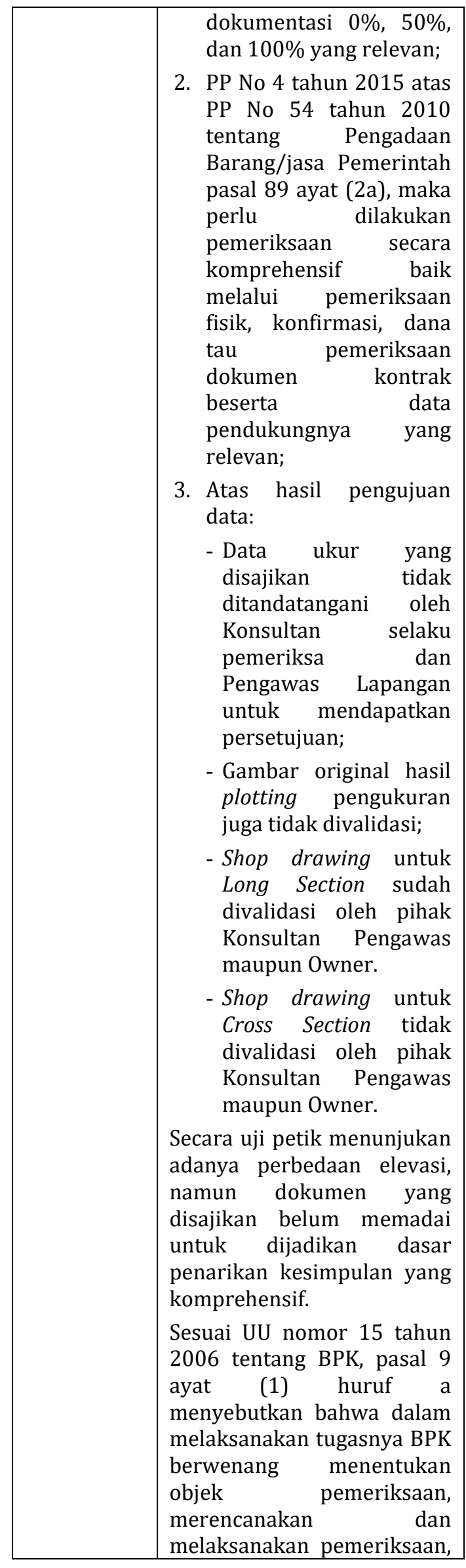

\begin{tabular}{|l|l|}
\hline mennetukan waktu dan \\
metode pemeriksaan serta \\
menyusun dan menyajikan \\
laporan pemeriksaan. \\
Maka, apabila diperlukan \\
pendalaman pemeriksaan \\
atas paket tersebut akan \\
dilaksanakan pada saat \\
pemeriksaan atas Laporan \\
Keuangan Kementerian \\
PUPR TA 2018.
\end{tabular}

\section{Kasus pengaduan 2}

Surat pengaduan tanggal 14 Februari 2019 yang mengadukan dugaan penyimpangan paket peningkatan embung jangkar Desa Sindang, Kabupaten Indramayu. Setelah dilakukan penelaahan secara desk audit, diketahui bahwa BPK belum dapat menyimpulkan apakah dugaan sebagaimana disampaikan dalam pokok surat tersebut benar-benar terjadi. Hal ini disebabkan informasi pokok pengaduan tidak didukung dokumen yang memadai sebagai dasar BPK melakukan analisis awal secara objektif dan komprehensif. BPK dapat menjadikan pengaduan sebagai informasi awal dalam pemeriksaan berikutnya.

Tabel 2. Ringkasan Kasus Pengaduan 2

\begin{tabular}{|c|c|}
\hline Judul & $\begin{array}{lr}\text { Penyampaian pengaduan } \\
\text { terkait } \\
\text { penyimpangan } \\
\text { peningkatan } \\
\text { jangkaket Desa } \\
\text { Kabupaten Indramayu dari } \\
\text { LSM TPN }\end{array}$ \\
\hline Via & Surat \\
\hline No Surat & 106/TPN-RI/II/2019 \\
\hline Tanggal & 14 Februari 2019 \\
\hline $\begin{array}{l}\text { No, tanggal } \\
\text { kontrak }\end{array}$ & - \\
\hline Asal dana & $\begin{array}{lcl}\text { APBN } & \text { TA } & 2018 \\
\text { (Kementerian PUPR) } & \end{array}$ \\
\hline Isi pengaduan & $\begin{array}{l}\text { Terdapat penyimpangan } \\
\text { karena dalam pelaksanaan } \\
\text { kegiatan tersebut tidak } \\
\text { sesuai dengan ketentuan } \\
\text { RAB dan telah merugikan } \\
\text { negara, diantaranya: Proyek }\end{array}$ \\
\hline
\end{tabular}




\begin{tabular}{|c|c|}
\hline & $\begin{array}{l}\text { Peningkatan } \\
\text { Jangkar Desa } r \text { Sindang } \\
\text { Kabupaten Indramayu } \\
\text { banyak kejanggalan pada } \\
\text { waktu pelaksanaan kegiatan } \\
\text { dan disinyalir pihak } \\
\text { kontraktor pemenang lelang } \\
\text { terkesan tidak ada rasa } \\
\text { tanggung jawab kepada } \\
\text { masyarakat karena dalam } \\
\text { pelaksanaan kegiatan tidak } \\
\text { mengutamakan kualiatas } \\
\text { atau tidak mementingkan } \\
\text { azas manfaat untuk } \\
\text { kepentingan } \\
\text { masyarakat warga } \\
\text { masayarakat petani di } \\
\text { wilayah itu. }\end{array}$ \\
\hline \multicolumn{2}{|l|}{ Hasil kajian } \\
\hline $\begin{array}{l}\text { Dasar } \\
\text { Penugasan } \\
\text { Pemeriksaan }\end{array}$ & Surat pengaduan terkait \\
\hline $\begin{array}{l}\text { Data } \\
\text { Pekerjaan }\end{array}$ & $\begin{array}{l}\text { Paket Pekerjaan } \\
\text { Peningakatan Embung } \\
\text { Jangkar Desa Sindang } \\
\text { Kabupaten Indramayu } \\
\text { Pihak Ketiga : PT D } \\
\text { No Kontrak } \\
\text { HK.02.03/At-4/05/01- } \\
02 / 2018 \\
\text { Tanggal Kontrak : } 2 \text { April } \\
2018 \\
\text { Waktu : } 240 \text { hari } \\
\text { kalender } \\
\text { Nilai Kontrak } \\
\text { Rp9.914.577.000,00 } \\
\text { Satker : SNVT } \\
\text { Pembangunan Bendungan } \\
\text { BBWS-CC }\end{array}$ \\
\hline \multicolumn{2}{|l|}{ Kasus Posisi } \\
\hline Permasalahan & $\begin{array}{l}\text { Proyek peningkatan embung } \\
\text { jangkar Desa Sindang } \\
\text { Kabupaten Indramayu } \\
\text { berkualitas buruk, diduga } \\
\text { adanya persekongkolan } \\
\text { serta persaingan usaha tidak } \\
\text { sehat yang menimbulkan } \\
\text { lemahnya pengawasan } \\
\text { dalam pelaksanaan kegiatan } \\
\text { sehingga pihak kontraktor } \\
\text { pemenang lelang dengan } \\
\text { leluasa melaksanakan } \\
\text { kegiatan tersebut dengan } \\
\text { cara mengenyampingkan }\end{array}$ \\
\hline
\end{tabular}

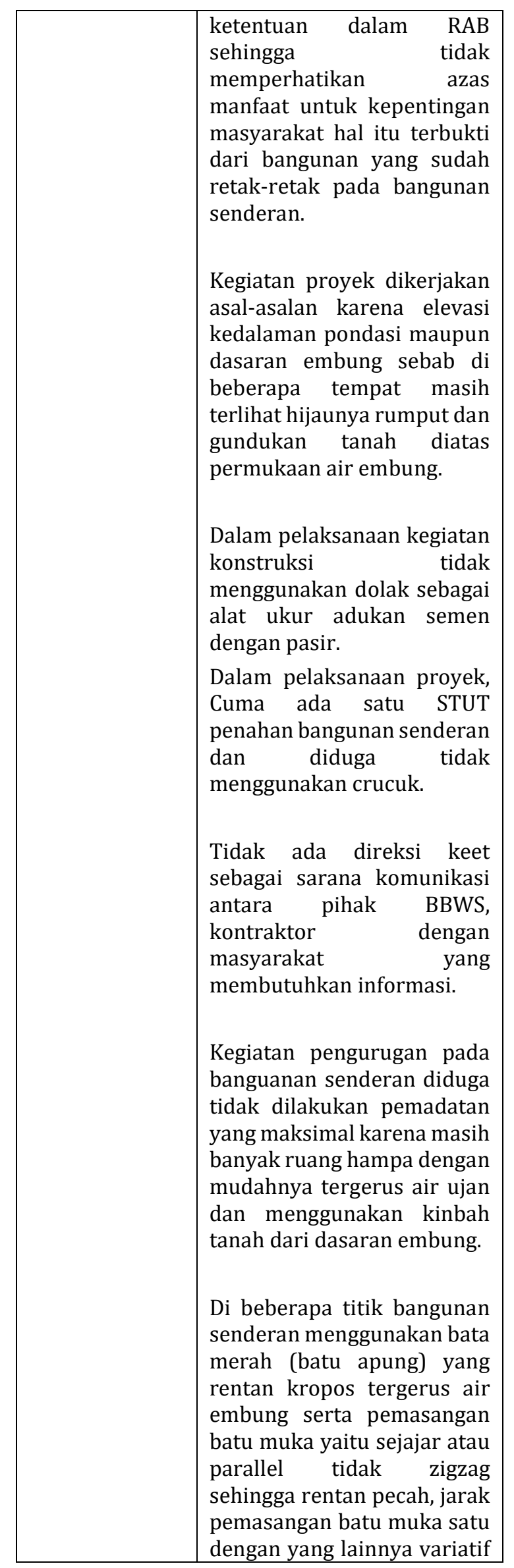




\begin{tabular}{|c|c|}
\hline & $\begin{array}{l}\text { yakni } 4 \text { sampai } 6 \mathrm{~cm} \text { yang } \\
\text { diduga tidak sesuai dengan } \\
\text { RAB. } \\
\text { Hasil akhir dari pelaksanaan } \\
\text { kegiatan, sepanjang } \\
\text { bangunan tidak ada sulingan } \\
\text { di bangunan senderan atau } \\
\text { paralon pembuangair hujan, } \\
\text { di beberapa titik sudah } \\
\text { terjadi kelongsoran dan } \\
\text { kemiringan. an kak } \\
\text { Disinyalir pihak kontraktor } \\
\text { tidak ada } \\
\text { tanggungjawab kada } \\
\text { masyarakat karena tidak } \\
\text { mengutamakan kualitas atau } \\
\text { tidak mementingkan azas } \\
\text { manfaat. }\end{array}$ \\
\hline Batasan & $\begin{array}{l}\text { Kajian dilakukan hanya } \\
\text { berdasarkan atas dokumen } \\
\text { pendukung yang ada dalam } \\
\text { surat pengaduan. }\end{array}$ \\
\hline \multirow[t]{3}{*}{ Hasil Kajian } & $\begin{array}{l}\text { Informasi pengaduan tidak } \\
\text { didukung dengan } \\
\text { kelengkapan dokumen yang } \\
\text { memadai antara lain } \\
\text { meliputi sekurang- } \\
\text { kurangnya: Dokumen } \\
\text { kontrak dan perubahannya } \\
\text { termasuk kuantitas dan } \\
\text { harga, dokumen gambar } \\
\text { yang lengkap (shop drawing } \\
\text { dan as built drawing) yang } \\
\text { lengkap, meliputi gambar } \\
\text { layout dan gambar detail, } \\
\text { back up data kuantitas dan } \\
\text { kualitas, justifikasi teknis, } \\
\text { Laporan harian, laporan } \\
\text { mingguan dan laporan } \\
\text { bulanan, foto dokumentasi } \\
\text { 0\%, 50\%, dan 100\% untuk } \\
\text { setiap item pekerjaan. } \\
\text { Sehingga: }\end{array}$ \\
\hline & $\begin{array}{l}\text { Terkait elevasi kedalaman } \\
\text { embung, tidak dapat } \\
\text { memastikan gundukan dan } \\
\text { tanaman yang ada menjadi } \\
\text { lingkup penanganan atau } \\
\text { tidak }\end{array}$ \\
\hline & $\begin{array}{l}\text { Terkait penggunaan Dolak } \\
\text { sebagai alat ukur, tidak data } \\
\text { melakukan analisis lebih }\end{array}$ \\
\hline
\end{tabular}

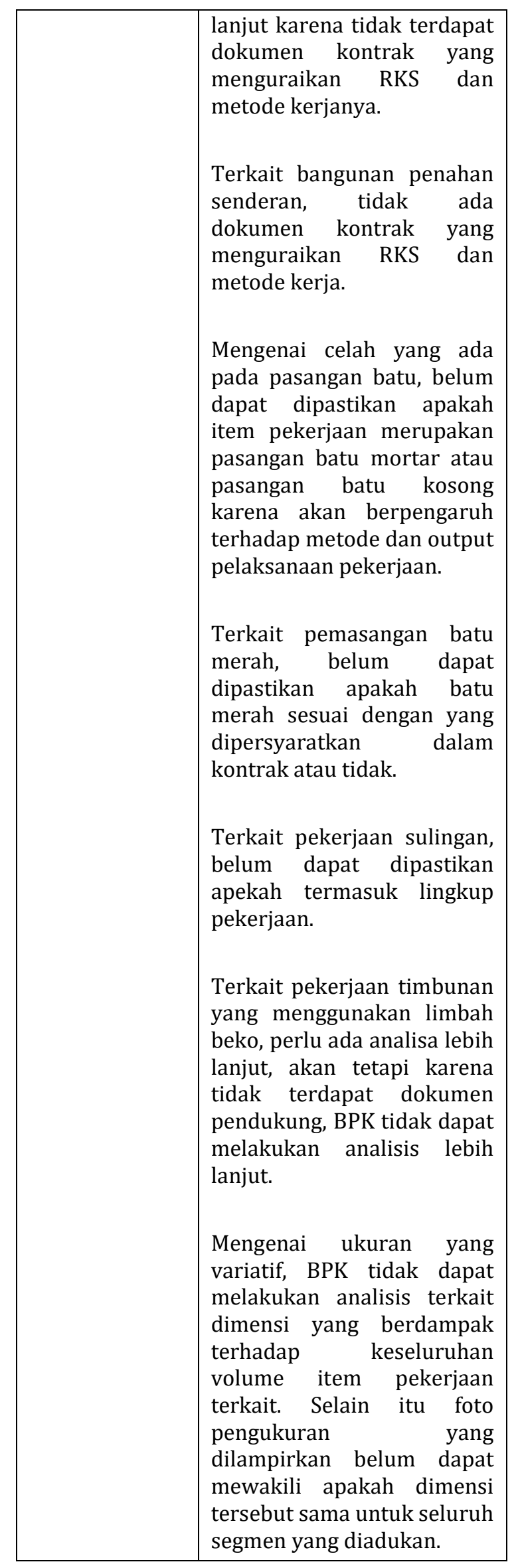




\begin{tabular}{|c|c|}
\hline Simpulan & $\begin{array}{l}\text { Berdasarkan uraian diatas, } \\
\text { dapat disimpulkan bahwa } \\
\text { BPK belum dapat } \\
\text { menyimpulkan apakah } \\
\text { dugaan sebagaimana } \\
\text { disampaikan dalam pokok } \\
\text { surat tersebut benar-benar } \\
\text { terjadi. Hal ini disebabkan } \\
\text { informasi pokok pengaduan } \\
\text { tidak didukung dokumen } \\
\text { yang memadai sebagai dasar } \\
\text { BPK melakukan analisis } \\
\text { awal secara objektif dan } \\
\text { komprehensif. }\end{array}$ \\
\hline $\begin{array}{l}\text { Surat } \\
\text { Tanggapan } \\
\text { BPK }\end{array}$ & \\
\hline Nomor Surat & 148/S/X.2/05/2019 \\
\hline Asal Surat & $\begin{array}{l}\text { Biro Humas dan Kerja Sama } \\
\text { Internasional (PPID) - BPK } \\
\text { RI }\end{array}$ \\
\hline Tujuan Surat & Sdr. DH \\
\hline Perihal & $\begin{array}{l}\text { Tanggapan atas surat } \\
\text { pengaduan LSM T }\end{array}$ \\
\hline Isi & $\begin{array}{l}\text { Informasi yang menjadi } \\
\text { pokok pengaduan tidak } \\
\text { didukung dengan } \\
\text { kelengkapan dokumen yang } \\
\text { memadaim antara lain: } \\
\text { a. Dokumen kontrak dan } \\
\text { perubahannya termasuk } \\
\text { kuantitas dan harga; } \\
\text { b. Dokumen gambar yang } \\
\text { lengkap (shop drawing } \\
\text { dan as built drawing) } \\
\text { yang lengkap, meliputi } \\
\text { gambar layout dan } \\
\text { gambar detail; } \\
\text { c. Back up data kuantitas } \\
\text { dan kualitas; } \\
\text { d. Justifikasi teknis; } \\
\text { e. Laporan harian, laporan } \\
\text { mingguan dan laporan } \\
\text { bulanan; } \\
\text { f. Foto dokumentasi 0\%, } \\
\text { 50\%, dan 100\% untuk } \\
\text { setiap item pekerjaan, } \\
\text { Berdasarkan hal tersebut, } \\
\text { BPK tidak dapat melakukan } \\
\text { analisis lebih lanjut atas } \\
\text { informasi pokok pengaduan. }\end{array}$ \\
\hline
\end{tabular}

\begin{tabular}{|l|l|}
\hline & $\begin{array}{l}\text { Tetapi pengaduan akan } \\
\text { digunakan sebagai informasi } \\
\text { awal dalam pemeriksaan } \\
\text { berikutnya. }\end{array}$ \\
\hline
\end{tabular}

\section{Kasus pengaduan 3}

Surat pengaduan tanggal 28 Januari 2020 yang mengadukan pengerjaan proyek melewati masa kontrak, adanya indikasi pembangunan proyek yang tidak sesuai dengan $\mathrm{RAB}$, dan dugaan pekerjaan tidak sesuai spesifikasi. Setelah dilakukan penelaahan secara desk audit, BPK belum dapat menyimpulkan apakah terdapat penyimpangan dalam pelaksanaan penggantian jembatan Indano Oou karena tidak terdapat dukungan data/dokumen yang memadai sebagai bahan untuk analisis lebih lanjut.

Tabel 3. Ringkasan Kasus Pengaduan 3

\begin{tabular}{|c|c|}
\hline Judul & $\begin{array}{l}\text { Pengaduan masyarakat } \\
\text { terkait Permohonan } \\
\text { Pemeriksaan } \\
\text { Pembangunan Jembatan } \\
\text { Sungai Idano Oou di } \\
\text { Sumatera Utara }\end{array}$ \\
\hline Via & Surat \\
\hline No Surat & $\begin{array}{l}\text { 01/Lp-Ms/DS } \\
\text { Amuri/XI/2019, } \\
\text { Januari } 2019 \\
\text { 02/Lp-Ms/DS } \\
\text { Amuri/III/2019, } \\
\text { Maret 2019 }\end{array}$ \\
\hline Tanggal & 28 Januari 2020 \\
\hline $\begin{array}{l}\text { No, tanggal } \\
\text { kontrak }\end{array}$ & - \\
\hline Asal dana & APBN TA 2018 \\
\hline Isi pengaduan & $\begin{array}{lr}\text { - } \begin{array}{lr}\text { Proyek masih dalam } \\
\text { proses pengerjaan }\end{array} \\
\text { bahkan sampai surat } \\
\text { dikirimkan ke } \\
\text { padahal berdasarkan } \\
\text { hasil penelusuran } \\
\text { bahwa r } \\
\text { pengerjaan } & \text { masa } \\
\text { mulai } 20 & \text { April } 2018 \\
\text { sampai } & \text { dengan } \\
\text { Desember } & 2018, \\
\text { dengan } & \text { masa }\end{array}$ \\
\hline
\end{tabular}




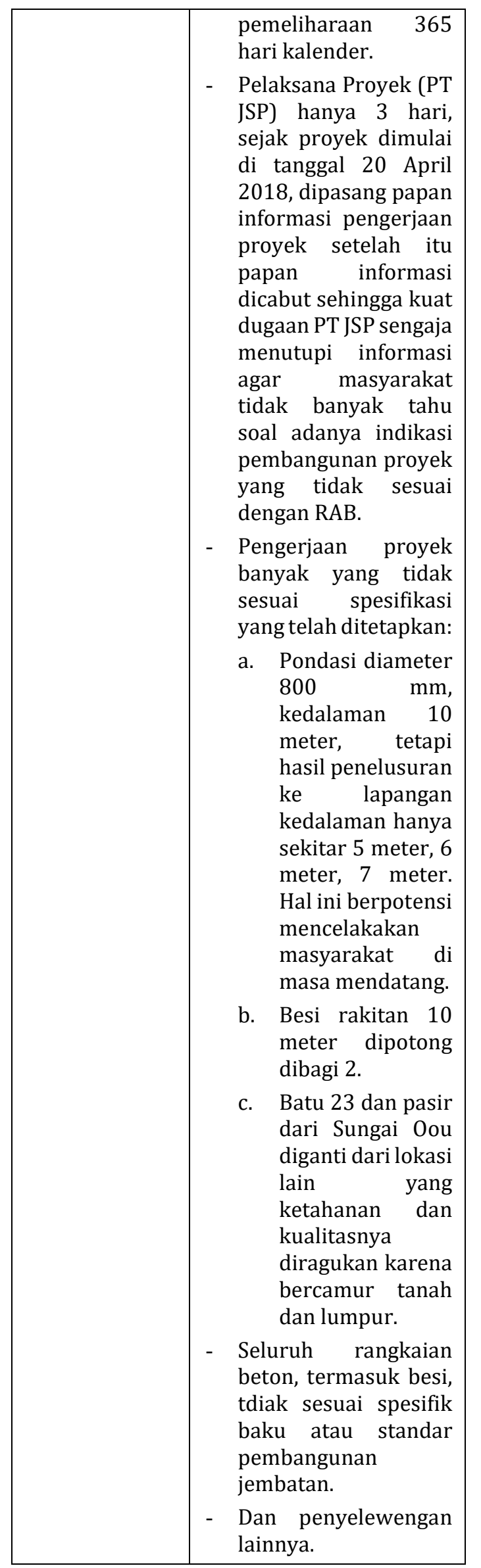

\begin{tabular}{|c|c|}
\hline Hasil telaah & \multirow[b]{2}{*}{ Surat pengaduan terkait } \\
\hline $\begin{array}{ll}f . & \text { Dasar } \\
& \text { Penugasan } \\
& \text { Pemeriksa } \\
& \text { an }\end{array}$ & \\
\hline $\begin{array}{ll}\text { g. } & \text { Data } \\
\text { Pekerjaan }\end{array}$ & $\begin{array}{l}\text { - } \text { Paket Pekerjaan: } \\
\text { Penggantian Jembatan } \\
\text { Indano Oou } \\
\text { - Pihak Ketiga: PT JSP } \\
\text { - No Kontrak: } \\
\text { PW.04.01/Bb- } \\
\text { WilS7/0382 } \\
\text { - Tanggal Kontrak: } 20 \\
\text { April 2018 } \\
\text { - Waktu: } 365 \quad \text { hari } \\
\text { kalender } \\
\text { - Satker: BBPJN II }\end{array}$ \\
\hline $\begin{array}{l}\text { h. Kasus } \\
\text { Posisi }\end{array}$ & - \\
\hline $\begin{array}{l}\text { i. Permasala } \\
\text { han }\end{array}$ & $\begin{array}{lr}\text { - Proyek masih dalam } \\
\text { proses pengerjaan } \\
\text { bahkan sampai surat } \\
\text { dikirimkan ke BPK, } \\
\text { padahal berdasarkan } \\
\text { hasil penelusuran } \\
\text { bahwa rasa } \\
\text { pengerjaan proyek } \\
\text { mulai } 20 \text { April } 2018 \\
\text { sampai rengan } \\
\text { Desember } 2018, \\
\text { dengan } \quad \text { masa } \\
\text { pemeliharaan } 365 \\
\text { hari kalender. } \\
\text { - Pelaksana Proyek (PT } \\
\text { JSP) hanya } 3 \text { hari, } \\
\text { sejak proyek dimulai } \\
\text { di tanggal } 20 \text { April } \\
\text { 2018, dipasang papan } \\
\text { informasi pengerjaan } \\
\text { proyek setelah itu } \\
\text { papan informasi } \\
\text { dicabut sehingga kuat } \\
\text { dugaan PT JSP sengaja } \\
\text { menutupi informasi } \\
\text { agar masyarakat } \\
\text { tidak banyak tahu } \\
\text { soal adanya indikasi } \\
\text { pembangunan proyek } \\
\text { yang tidak sesuai } \\
\text { dengan RAB. } \\
\text { Pengerjaan proyek } \\
\text { banyak yang tidak }\end{array}$ \\
\hline
\end{tabular}




\begin{tabular}{|c|c|}
\hline & $\begin{array}{l}\text { sesuai spesifikasi } \\
\text { yang telah ditetapkan: } \\
\text { a. Pondasi diameter } \\
800 \text { mm, } \\
\text { kedalaman } 10 \\
\text { meter, tetapi hasil } \\
\text { penelusuran ke } \\
\text { lapangan } \\
\text { kedalaman hanya } \\
\text { sekitar } 5 \text { meter, } 6 \\
\text { meter, } 7 \text { meter. } \\
\text { Hal ini berpotensi } \\
\text { mencelakakan } \\
\text { masyarakat di } \\
\text { masa mendatang; } \\
\text { b. Besi rakitan } 10 \\
\text { meter dipotong } \\
\text { dibagi } 2 \text {; } \\
\text { c. Batu } 23 \text { dan pasir } \\
\text { dari Sungai Oou } \\
\text { diganti dari lokasi } \\
\text { lain y dang } \\
\text { ketahanan dan } \\
\text { kualitasnya } \\
\text { diragukan karena } \\
\text { bercampur tanah } \\
\text { dan lumpur. } \\
\text { Seluruh rangkaian } \\
\text { beton, termasuk besi, } \\
\text { tdiak sesuai spesifik } \\
\text { baku atau standar } \\
\text { pembangunan } \\
\text { jembatan. } \\
\text { Dan penyelewengan } \\
\text { lainnya. }\end{array}$ \\
\hline $\begin{array}{l}\text { a. Hasil } \\
\text { Telaahan }\end{array}$ & $\begin{array}{lr}\text { - Pengaduan ini tidak } \\
\text { didukung dengan foto } \\
\text { dokumentasi pekerjaan } \\
\text { di masa akhir kontrak } \\
\text { (0\%,50\% dan } 100 \% \text { ), } \\
\text { dokumen hasil } \\
\text { pengukuran (terkait } \\
\text { kedalaman yang } \\
\text { menyebutkan ukuran), } \\
\text { dokumen hasil } \\
\text { laboratorium (terkait } \\
\text { dengan kualitas bahan, } \\
\text { batu, pasir), spesifikasi } \\
\text { beton, RAB, metode } \\
\text { pelaksanaan pekerjaan, } \\
\text { kontrak dan } \\
\text { kelengkapannya } \\
\text { termasuk addendum, } \\
\text { back up data, gambar } \\
\text { (As Build Drawing dan }\end{array}$ \\
\hline
\end{tabular}

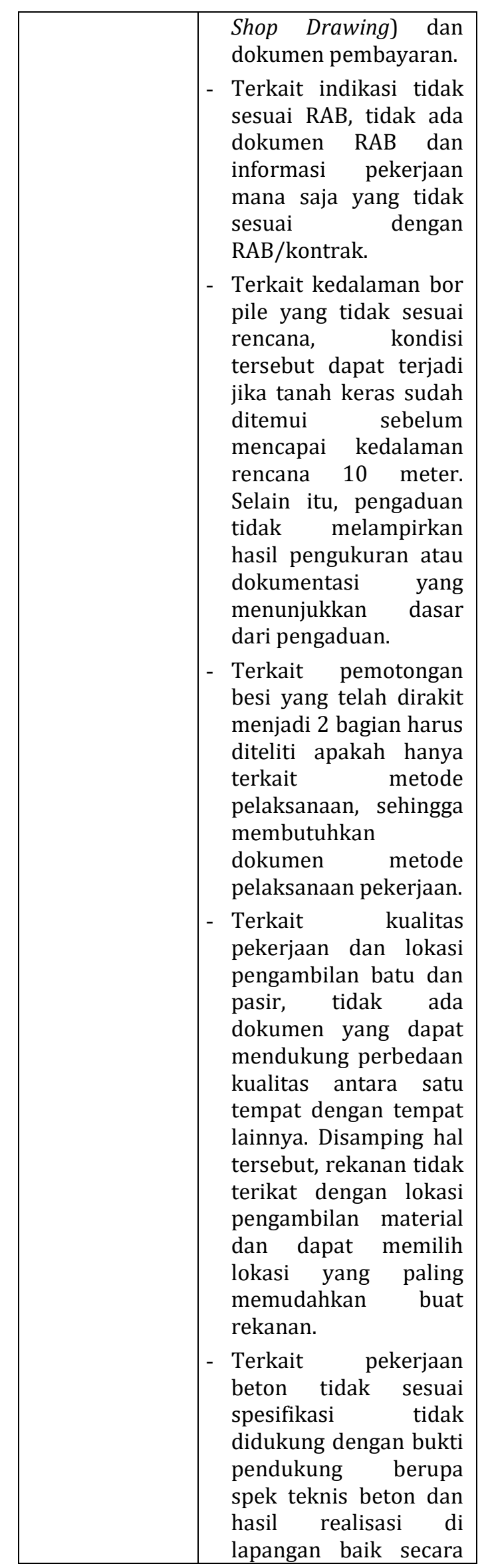




\begin{tabular}{|c|c|}
\hline & $\begin{array}{ll}\text { kualitas } & \text { maupun } \\
\text { kuantitas. } & \end{array}$ \\
\hline b. Simpulan & 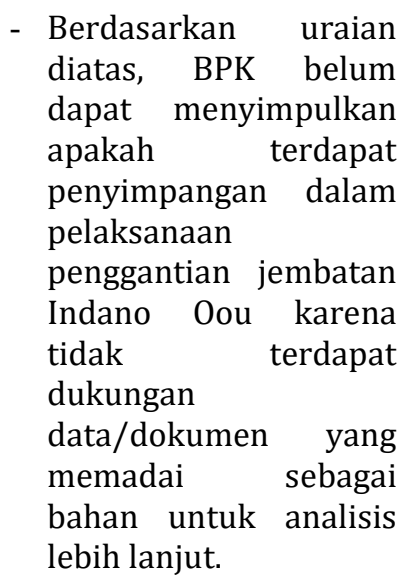 \\
\hline \multicolumn{2}{|c|}{ Surat Tanggapan BPK } \\
\hline $\begin{array}{ll}\text { a. } & \text { Nomor } \\
\text { Surat }\end{array}$ & 187/S/X.2/05/2019 \\
\hline b. Asal Surat & $\begin{array}{l}\text { Biro Humas dan Kerja } \\
\text { Sama Internasional } \\
\text { (PPID) - BPK RI }\end{array}$ \\
\hline $\begin{array}{l}\text { c. Tujuan } \\
\text { Surat }\end{array}$ & Sdri. GL \\
\hline d. Perihal & $\begin{array}{l}\text { Tanggapan BPK atas } \\
\text { Pengaduan Masyarakat }\end{array}$ \\
\hline e. Isi & $\begin{array}{l}\text { Berdasarkan telaah atas } \\
\text { pengaduan masyarakat } \\
\text { yang Saudara sampaikan, } \\
\text { dapat kami informasikan } \\
\text { bahwa BPK belum dapat } \\
\text { menyimpulkan apakah } \\
\text { terdapat penyimpangan } \\
\text { dalam pelaksanaan } \\
\text { penggantian jembatan } \\
\text { Indano Oou karena tidak } \\
\text { terdapat dukungan } \\
\text { data/dokumen yang } \\
\text { memadai sebagai bahan } \\
\text { untuk analisis lebih } \\
\text { lanjut. }\end{array}$ \\
\hline
\end{tabular}

\section{Kasus pengaduan 4}

Surat pengaduan tanggal 5 Desember 2019 yang mengadukan dugaan permasalahan tata kelola dan pembelian limbah B3. Setelah dilakukan penelaahan secara desk audit, BPK belum bisa membuktikan pengaduan yang disampaikan pengadu, namun hanya terbatas memberikan informasi bahwa benar PT. LPS telah berkontrak dan melakukan pengangkutan 5.000 MT dari PT.
KS dan dalam hal ini PT. LPS telah memenuhi ketentuan karena telah memiliki izin pengelolaan limbah B3. Untuk pemeriksaan lebih lanjut, BPK menyatakan belum bisa dilakukan pemeriksaan lebih lanjut atas pengujian lapangan karena kebijakan sistem WFH yang diterapkan BPK dan PT. KS.

Tabel 4. Ringkasan Kasus Pengaduan 4

\begin{tabular}{|c|c|}
\hline Judul & $\begin{array}{l}\text { Pengaduan terkait } \\
\text { dugaan permasalahan } \\
\text { tata kelola dan pembelian } \\
\text { limbah B3 yang } \\
\text { dihasilkan oleh PT KS dan } \\
\text { PT PBH }\end{array}$ \\
\hline Via & Surat \\
\hline Tanggal & 5 Desember 2019 \\
\hline $\begin{array}{l}\text { No tanggal } \\
\text { kontrak }\end{array}$ & - \\
\hline Asal dana & - \\
\hline Isi pengaduan & 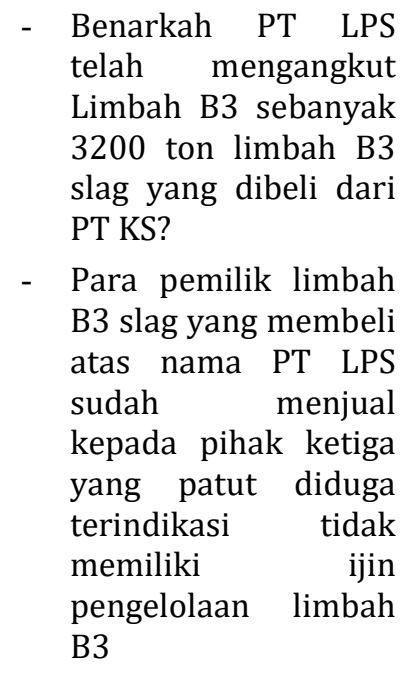 \\
\hline \multicolumn{2}{|l|}{ Hasil telaah } \\
\hline $\begin{array}{ll}\text { c. Dasar } \\
\\
\text { Penugasan } \\
\text { Telaah }\end{array}$ & Surat pengaduan terkait \\
\hline d. $\begin{array}{r}\text { Kasus } \\
\text { Posisi }\end{array}$ & $\begin{array}{l}\text { - Permasalahan yang } \\
\text { diadukan adalah terkait } \\
\text { tata kelola dan } \\
\text { pembelian limbah B3 } \\
\text { Slag yang dibeli dari PT } \\
\text { KS dan patut diduga } \\
\text { para pemilik limbah B3 } \\
\text { slag yang membeli atas } \\
\text { nama PT LPS (LPS) } \\
\text { menjual kepada pihak } \\
\text { ketiga yang patut }\end{array}$ \\
\hline
\end{tabular}




\begin{tabular}{|c|c|}
\hline & $\begin{array}{l}\text { diduga terindikasi tidak } \\
\text { memiliki ijin } \\
\text { pengelolaan limbah B3; } \\
\text { - } \text { Pelaksana: PT LPS dan } \\
\text { PT KS; } \\
\text { - PT LPS telah } \\
\text { berkontrak dengan PT } \\
\text { KS untuk membeli } \\
\text { 5.000 MT limbah B3 } \\
\text { slag pada tanggal 19 } \\
\text { Maret 2019 dengan } \\
\text { loco Gudang PT KS di } \\
\text { Cilegon. Dalam } \\
\text { melaksanakan kontrak } \\
\text { tersebut PT LPS telah } \\
\text { mendapat ijin } \\
\text { pemanfaatan limbah B3 } \\
\text { slag dari Kementerian } \\
\text { Lingkungan Hidup dan } \\
\text { Kehutanan Republik } \\
\text { Indonesia (SK no. } \\
\text { 436/Menlhk/Setjen/P } \\
\text { LB.3/6/2016 tentang } \\
\text { Izin Pengelolaan } \\
\text { Limbah Bahan } \\
\text { Berbahaya dan Beracun } \\
\text { Untuk Kegiatan } \\
\text { Pemanfaatan Limbah } \\
\text { Bahan Berbahaya dan } \\
\text { Beracun an. PT LPS; } \\
\text { - Jangka waktu izin } \\
\text { pengelolaan limbah: } 5 \\
\text { tahun (terhitung 14 } \\
\text { Juni 2016). }\end{array}$ \\
\hline $\begin{array}{l}\text { e. Permasala } \\
\text { han }\end{array}$ & $\begin{array}{l}\text { - Apakah benar PT LPS } \\
\text { telah mengangkut } \\
\text { Limbah B3 sebanyak } \\
3200 \text { ton limbah B3 } \\
\text { slag yang dibeli dari PT } \\
\text { KS? } \\
\text { - Apakah benar para } \\
\text { pemilik limbah B3 slag } \\
\text { yang membeli atas } \\
\text { nama PT LPS sudah } \\
\text { menjual kepada pihak } \\
\text { ketiga yang patut } \\
\text { diduga terindikasi tidak } \\
\text { memiliki ijin } \\
\text { pengelolaan limbah B3 }\end{array}$ \\
\hline $\begin{array}{ll}f . & \text { Hasil } \\
& \text { Telaahan }\end{array}$ & $\begin{array}{l}\text { - Dari hasil penjelasan } \\
\text { PT KS dan dokumen } \\
\text { yang disampaikan ke } \\
\text { BPK dapat disimpulkan } \\
\text { bahwa benar PT LPS } \\
\text { telah berkontrak dan } \\
\text { telah melakukan }\end{array}$ \\
\hline
\end{tabular}

\begin{tabular}{|c|c|}
\hline & $\begin{array}{lr}\text { pengangkutan } & 5.000 \\
\text { MT. } & \\
\text { - Untuk membuktikan } \\
\text { apakah pemilik limbah } \\
\text { B3 yang membeli atas } \\
\text { nama PT LPS kemudian } \\
\text { menjualnya repada } \\
\text { pihak ketiga yang tidak } \\
\text { memiliki } & \text { izin } \\
\text { pengelolaan r limbah } \\
\text { dilaksanakan } & \text { melalui } \\
\text { pemeriksaan } & \text { sesuai } \\
\text { Surat Tugas } & \text { Anggota } \\
\text { VII BPK RI } & \text { Nomor: } \\
\text { 11/ST/IX- } & \\
\text { XX.2/02/2020 } & \text { tanggal } \\
\text { 28 Februari } & \text { 2020. } \\
\text { Namun pemeriksaan } \\
\text { hanya bias } & \text { berjalan } \\
\text { satu minggu } & \text { karena } \\
\text { penetapan } & \text { status } \\
\text { Kejadian Luar } & \text { Biasa } \\
\text { (KLB) virus corona oleh } \\
\text { Pemerintah } & \text { Provinsi } \\
\text { Banten, } & \text { sehingga } \\
\text { sampai dengan } & \text { saat ini } \\
\text { BPK belum } & \text { dapat } \\
\text { melaksanakan } & \\
\text { pemeriksaan } & \text { terinci } \\
\text { terkait hal tersebut. }\end{array}$ \\
\hline g. Simpulan & $\begin{array}{l}\text { - BPK belum bisa } \\
\text { membuktikan } \\
\text { pengaduan yang } \\
\text { disampaikan pengadu, } \\
\text { namun hanya terbatas } \\
\text { memberikan informasi } \\
\text { bahwa benar PT LPS } \\
\text { telah berkontrak dan } \\
\text { melakukan } \\
\text { pengangkutan } 5.000 \\
\text { MT dari PT KS dan } \\
\text { dalam hal ini PT LPS } \\
\text { telah memenuhi } \\
\text { ketentuan karena telah } \\
\text { memiliki izin } \\
\text { pengelolaan limbah B3. }\end{array}$ \\
\hline \multicolumn{2}{|l|}{$\begin{array}{l}\text { Surat } \\
\text { Tanggapan } \\
\text { BPK }\end{array}$} \\
\hline $\begin{array}{ll}f . & \text { Nomor } \\
& \text { Surat }\end{array}$ & 139/S/X.2/04/2020 \\
\hline g. Asal Surat & Biro Humas \\
\hline $\begin{array}{l}\text { h. Tujuan } \\
\text { Surat }\end{array}$ & Sdr. MN \\
\hline
\end{tabular}




\begin{tabular}{|c|c|}
\hline i. Perihal & $\begin{array}{l}\text { Tanggapan BPK atas } \\
\text { pengaduan masyarakat } \\
\text { terkait tata kelola limbah } \\
\text { B3 pada PT KS }\end{array}$ \\
\hline j. Isi & 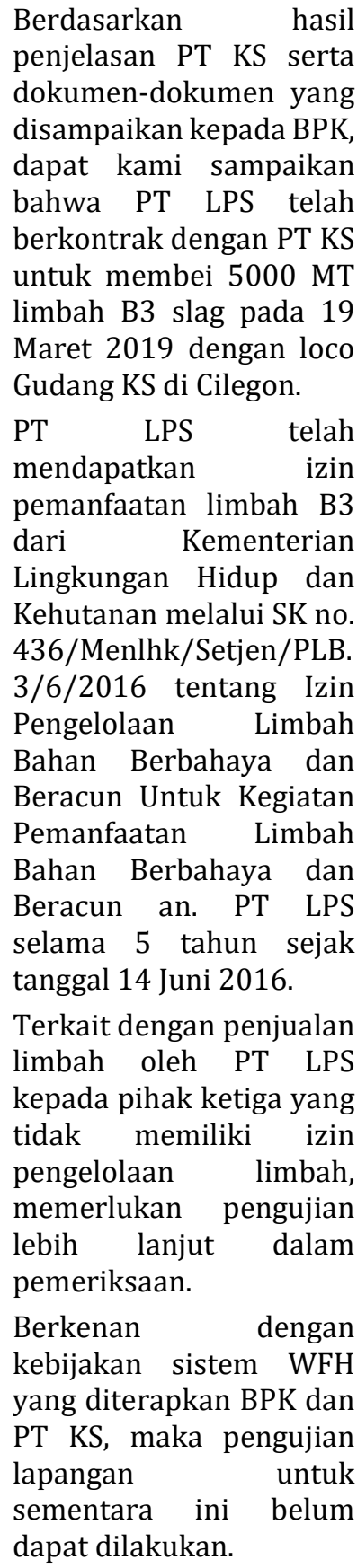 \\
\hline
\end{tabular}

\section{Kasus pengaduan 5}

Surat pengaduan tanggal 28 Januari 2020 yang mengadukan dugaan permasalahan yang terjadi pada UIN SSK Riau. Setelah dilakukan penelaahan secara desk audit, BPK memberikan jawaban bahwa UIN SSK Riau telah menjadi salah satu sampel dalam pemeriksaan BPK atas Laporan Keuangan Kementerian Agama Tahun Anggaran 2019.

Tabel 5. Ringkasan Kasus Pengaduan 5

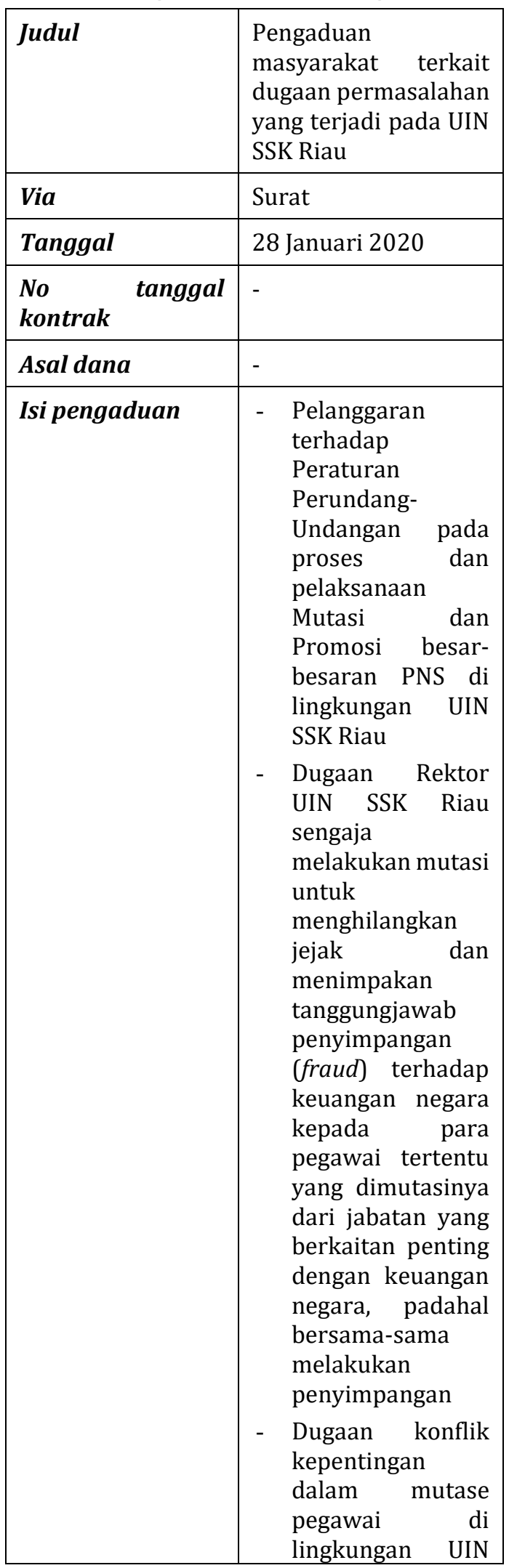




\begin{tabular}{|c|c|}
\hline & $\begin{array}{l}\text { SSK Riau yang } \\
\text { berkaitan penting } \\
\text { dengan } \\
\text { pengelolaan } \\
\text { keuangan dan } \\
\text { pengadaan barang } \\
\text { dan jasa pada UIN } \\
\text { SSK Riau pada } \\
\text { Tahun } 2019 \\
\text { - Dugaan tindak } \\
\text { pidana dalam } \\
\text { pengadaan barang } \\
\text { dan jasa UIN SSK } \\
\text { Riau }\end{array}$ \\
\hline \multicolumn{2}{|l|}{ Hasil telaah } \\
\hline $\begin{array}{l}\text { h. Dasar } \\
\text { Penugasan }\end{array}$ & $\begin{array}{l}\text { Surat pengaduan } \\
\text { terkait }\end{array}$ \\
\hline i. Kasus Posisi & 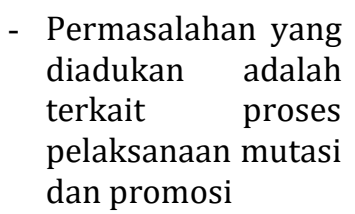 \\
\hline j. Permasalahan & - \\
\hline $\begin{array}{ll}\text { k. } & \text { Hasil } \\
& \text { Telaahan }\end{array}$ & - \\
\hline l. Simpulan & 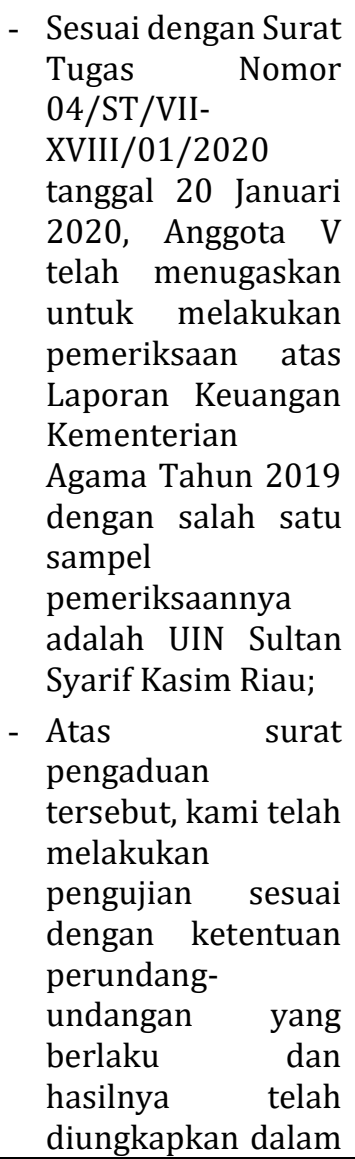 \\
\hline
\end{tabular}

\begin{tabular}{|c|c|}
\hline & $\begin{array}{l}\text { temuan } \\
\text { pemeriksaan. }\end{array}$ \\
\hline $\begin{array}{l}\text { Surat Tanggapan } \\
\text { BPK }\end{array}$ & \\
\hline k. Nomor Surat & 143/S/X.2/05/2020 \\
\hline I. Asal Surat & \\
\hline m. Tujuan Surat & Sdri. RR \\
\hline n. Perihal & $\begin{array}{l}\text { Tanggapan BPK atas } \\
\text { Pengaduan Dugaan } \\
\text { Kerugian Negara pada } \\
\text { UIN SSK Riau }\end{array}$ \\
\hline o. Isi & 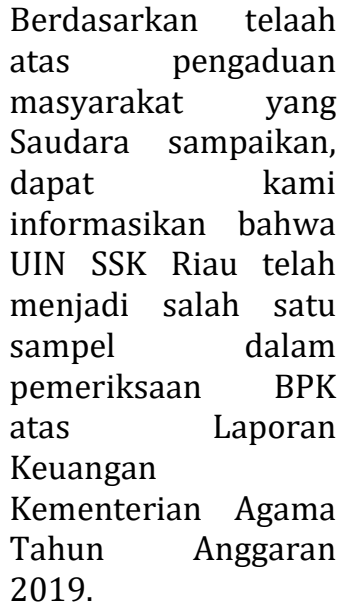 \\
\hline
\end{tabular}

\section{HASIL PEMBAHASAN}

Sesuai dengan pengaduan-pengaduan yang sudah dijabarkan diatas, menghasilkan beberapa jawaban diantaranya adalah:

Apabila diperlukan pendalaman pemeriksaan atas paket pekerjaan maka dapat dilaksanakan pada saat pemeriksaan BPK di tahun anggaran berikutnya;

BPK RI tidak dapat melakukan analisis lebih lanjut atas informasi pokok pengaduan. Tetapi pengaduan akan digunakan sebagai informasi awal dalam pemeriksaan berikutnya;

BPK RI belum dapat menyimpulkan apakah terdapat penyimpangan dalam pelaksanaan pekerjaan karena tidak terdapat dukungan data/ dokumen yang memadai sebagai bahan untuk analisis lebih lanjut;

Berkenaan dengan kebijakan sistem Work From Home (WFH) yang diterapkan BPK RI, maka pengujian lapangan untuk sementara ini belum dapat dilakukan; 
Objek yang diadukan sudah menjadi salah satu sampel dalam pemeriksaan BPK RI, dan telah melakukan pengujian sesuai dengan ketentuan perundanga-undangan yang berlaku dan hasilnya telah diungkapkan dalam temuan pemeriksaan.

\section{KESIMPULAN}

Berdasarkan permasalahan, tujuan dan hasil analisis tentang dukungan BPK RI dalam penyelesaian sengketa konstruksi disimpulkan sebagai berikut:

1. Hasil telaahan BPK atas pengaduan yang memenuhi ketentuan pengaduan di BPK RI dapat menjadi masukan/acuan/rujukan bagi pihakpihak yang bersengketa untuk menyelesaikan persengketaan secara musyawarah secara kekeluargaan (pasal 88 Undang-Undang nomor 2 tahun 2017) dan dapat menjadi cikal kriteria atau rujukan oleh masyarakat atau pelaku dunia konstruksi untuk meminimalisasi permasalahan konstruksi;

2. Belum ada keseragaman dalam pemberian rekomendasi oleh BPK RI yang diberikan atas permasalahan yang sejenis;

3. Terdapat perbedaan pemahaman dari pelaku jasa konstruksi dalam memahami ketentuan yang tercantum dalam perikatan dua pihak sehingga isi perikatan harus menggunakan Bahasa yang mudah dimengerti dan tidak menimbulkan misinterpretasi yang mengatur syarat-syarat umum dan khusus kontrak yang menjadi hak dan kewajiban serta konsekuensi bagi masing-masing pihak yang wanprestasi, pelaku jasa konstruksi harus secara rutin memperbaharui ilmu tentang kontrak konstruksi dan aturan-aturan terkait lainnya;

4. Hasil temuan pemeriksaan BPK RI yang terdapat dalam LHP yang sudah diterbitkan, dapat menjadi bahan masukan bagi pihak-pihak yang bersengketa dalam menghadapi permasalahan dalam pelaksanaan dunia konstruksi.

\section{DAFTAR PUSTAKA}

[1] Republik Indonesia. Undang-Undang No. 2 Tahun 2017 tentang Jasa Konstruksi. Lembaran Negara RI Tahun 2017. Sekretariat Negara. Jakarta. 2017.

[2] Republik Indonesia. Undang-Undang No. 23 tahun 2014 tentang Pemerintah Daerah. Lembaran Negara RI Tahun 2014. Sekretariat Negara. Jakarta. 2014.

[3] Republik Indonesia. Undang-Undang No. 15 Tahun 2006 tentang Badan Pemeriksa Keuangan. Lembaran Negara RI Tahun 2006. Sekretariat Negara. Jakarta. 2006.

[4] Republik Indonesia. Undang-Undang No. 15 Tahun 2004 tentang Pemeriksaan Pengelolaan dan Tanggung Jawab Keuangan Negara. Lembaran Negara RI Tahun 2004. Sekretariat Negara. Jakarta. 2004.

[5] Republik Indonesia. Undang-Undang No. 30 tahun 1999 tentang Arbitrase dan Alternatif Penyelesaian Sengketa. Lembaran Negara RI Tahun 1999. Sekretariat Negara. Jakarta. 1999.

[6] Republik Indonesia. Undang-Undang No. 18 Tahun 1999 tentang Jasa Konstruksi. Lembaran Negara RI Tahun 1999. Sekretariat Negara. Jakarta. 1999.

[7] 1847. Kitab Undang-Undang Hukum Perdata. Tentang Burgerlijk Wetboek voor Indonesie. 1847.

[8] Ervianto, W. Manajemen Proyek Konstruksi (Edisi Revisi). Yogyakarta: Andi. 2005.

[9] Garner, B.A. Black's Law Dictionary, Eight Edition. USA: Thomson West. 2004.

[10] Hardjomuljadi, Sarwono. Alternatif Penyelesaian Sengketa Konstruksi di Indonesia Buku Ketiga. Bandung: Logoz Publishing. 2016. 
[11] Soeharto, Imam. Manajemen Proyek Edisi kedua. Jakarta: Penerbit Erlangga. 1999.

[12] Djatnika, Suntana. Hand Out Workshop: Tata Cara Berkontrak Konstruksi dan Penyelesaian Sengketa. 2018.

[13] Hardjomuljadi, Sarwono. Use of Dispute Avoidance and Adjudication Boards. No. Jurnal 03720004. Dispute Resolut. Eng. Constr., 12(4), hal 2. 2020.

[14] Direktorat Jenderal Bina Konstruksi Kementerian Pekerjaan Umum dan Perumahan Rakyat. Permasalahan Kontrak Konstruksi. website SIBIMA. 2016. 
